\title{
WISATA KELAUTAN BERKELANJUTAN DI LABUANBAJO, NUSA TENGGARA TIMUR: SEBUAH STUDY TENTANG PERSEPSI MASYARAKAT KAWASAN PESISIR
}

\author{
Alexander M. A. Khan \\ Fakultas Perikanan dan Ilmu Kelautan Universitas Padjadjaran, Bandung \\ Email: alexander.khan@unpad.ac.id \\ Imam Musthofa \\ World Wildlife Foundation-Indonesia, Denpasar \\ Email: imusthofa@wwf.or.id \\ Indarwati Aminuddin \\ World Wildlife Foundation-Indonesia, Denpasar \\ Email: iaminuddin@wwf.id \\ Fitri Handayani \\ World Wildlife Foundation-Indonesia, Denpasar \\ Email: pittihandayani.fitri@gmail.com \\ Ratna N. Kuswara \\ World Wildlife Foundation-Indonesia, Denpasar \\ Email: ratnaningsihkuswara2502@gmail.com

\section{Ajeng Wulandari} \\ Fakultas Perikanan dan Ilmu Kelautan Universitas Padjadjaran, Bandung \\ Email: ajengwulandari74@gmail.com
}

\begin{abstract}
Community-based tourism is one type of tourism that involves community participation to achieve the goal of sustainable tourism development. The purpose of this study is to determine the tourism potential to be managed by the community based on people's perceptions of the existing tourism potential, as well as identifying people's perceptions of national, regional, and also traditional policies in tourism. This research was divided into several data collection, internal-external factor analysis, data analysis and development strategy analysis using the SWOT matrix. The conclusions of this study are (1) Natural resources in Labuan Bajo which can be used as tourist attractions that have not been managed and developed properly.
\end{abstract}


Those are Ara Mountain, Ina Mountain, Namong Island, Kelaki Island, Kima Island, Komodo, wild horses and buffalo, savannah, Rangka Cave, Gosong, Pasir Timbul, Mangrove and several underwater object such as Manta and coral reefs. (2) Based on a quantitative strategy, the development strategy that is suitable to be carried out in Labuan Bajo is the S-O Strategy which is carried out by utilizing the strength needed to achieve the opportunities that exist. (3) Based on a qualitative strategy, a suitable strategy to be carried out in Labuan Bajo is related to the improvement of public facilities, partnerships with universities, improvement of the people's economy, and the improvement of regional and group economies.

Keywords: Community based tourism, local communities, natural resources, potencies, SWOT analysis

\section{Pendahuluan}

Sektor pariwisata memiliki peran penting dalam meningkatkan perekonomian, baik perekonomian nasional, daerah, dan masyarakat sekitarnya dimana wisata alam tersebut berada. Keberadaan sumberdaya alam di suatu wilayah menyediakan jasa lingkungan berupa tata air, penyerapan karbon, penghasil oksigen, dan sebagainya (Nasution dkk., 2015). Selain itu, pemandangan dari bentang alam dan keanekaragaman ekosistem juga dapat dikategorikan sebagai jasa lingkungan yang dapat dirasakan oleh pengunjung. Salah satu wilayah di Indonesia yang memiliki keanekaragaman bentang alam yang dapat dikembangkan menjadi daerah tujuan wisata yang berbasis masyarakat adalah Labuanbajo, Nusa Tenggara Timur. Sebagaimana motto untuk kawasan Labuanbajo, yaitu "Pintu Gerbang Pariwisata dan Pendukung Pangan Nasional" memiliki berfungsi sebagai tiang penyangga pendapatan asli daerahnya (Mary dan Kristanto, 2013).

Pariwisata berbasis masyarakat merupakan salah satu jenis pariwisata yang melibatkan partisipasi aktif masyarakat sebagai unsur utama dalam pengelolaan pariwisata guna mencapai tujuan pembangunan pariwisata berkelanjutan (Telfer dan Sharpley, 2008 dalam Adikampana, 2017). Sebuah penelitian oleh Dewi (2013) dimana 
pengembangan daerah wisata membutuhkan keterlibatan seluruh masyarakat pada setiap tahapan pengembangan mulai dari perencanaan, pelaksanaan, hingga pengawasan. Keterlibatan masyarakat dalam kegiatan pengelolan wisata akan memberikan dampak dan kesempatan terbaik dalam manajemen dan pembangungan pariwisata yang berujung pada pemberdayaan masyarakat di lokasi tujuan wisata, hingga pada akhirnya pembagian keuntungan dari kegiatan pariwisata oleh seluruh pemangku kepentingan dalam pengelolaan pariwisata tersebut (Nurdin, 2016 dalam Allo dkk. 2018).

Berbagai penelitian mengenai pelibatan masyarakat dalam pengelolaan pariwisata telah banyak di lakukan di Indonesia. Salah satunya penelitian oleh Allo dkk (2018) di Kabupaten Tana Toraja menunjukkan bahwa pengelolaan pariwisata berbasis masyarakat [community-based tourism] memberikan dampak postif, diantaranya peningkatan ekonomi, pengembangan jiwa kewirausahaan dan kreatifitas masyarakat. Selanjutnya, sebuah penelitian oleh Salim dan Purbani (2015) tentang pengembangan pariwisata bahari berbasis masyarakat di Kaledupa, Kabupaten Wakatobi menunjukkan bahwa terdapat 3 (tiga) variabel utama dalam pengembangan wisata bahari di Kaledupa yaitu informatif, kordinasi antar instansi, dan sumberdaya alam. Penguatan dari variabel-variabel tersebut diharapkan dapat mengoptimalkan peran serta masyarakat sehingga dapat meningkatkan kepuasan wisatawan dan kesejahteraan masyarakat Pulau Kaledupa.

Penelitian ini bertujuan untuk mengetahui potensi wisata yang akan dikelola oleh masyarakat berdasarkan persepsi masyarakat terhadap potensi wisata yang ada, menentukan strategi pengelolaan pariwisata dan melakukan evaluasi terhadap kegiatan pariwisata berbasis masyarakat melalui persepsi masyarakat. 


\section{KERANGKA PIKIR}

Pariwisata berkelanjutan menurut The World Tourism Organization (WTO) dalam Gunawan dan Ortis (2012) adalah pariwisata yang memperhitungkan secara penuh dampak ekonomi, sosial dan lingkungan sekarang dan yang akan datang, menjawab kebutuhan pengunjung, industri (pariwisata), lingkungan, dan komunitas tuan rumah. Pariwisata berkelanjutan tidak hanya mengeksploitasi sumberdaya alam dan budaya, melainkan melakukan juga konservasi terhadap sumberdaya alami dan budaya, serta bertujuan untuk mendistribusikan keuntungan secara lebih luas diantara para pemangku kepentingan dan komunitas.

Adapun prinsip-prinsip pembangunan berkelanjutan dari pariwisata yang disebutkan dalam Gunawan dan Ortis (2012) sebagai keseimbangan yang harus dibentuk antara aspek lingkungan, ekonomi dan sosio-budaya dalam pembangunan kepariwisataan guna menjamin keberlangsungan kegiatan pariwisata dalam jangka panjang. Prinsip-prinsip tersebut adalah:

1. Memanfaatkan sumberdaya lingkungan sebagai elemen kunci dalam pembangunan kepariwisataan secara optimal.

2. Menghormati keotentikan sosio-budaya dan komunitas tuan rumah, melestarikan nilai-nilai tradisional dan berkontribusi terhadap pemahaman antar budaya dan toleransi.

3. Keberlangsungan jangka panjang yang bermanfaat secara sosio-ekonomi kepada semua pemangku kepentingan yang terdistribusi secara berkeadilan. Keberadaan partisipasi semua pemangku kepentingan yang mendapat informasi dan kepemimpinan politis yang kuat. Pemantauan secara konstan, menjaga tingkat kepuasan wisatawan yang tinggi, serta menumbuhkan kesadaran tentang isu-isu keberlanjutan dan mempromosikan praktek pariwisata berkelanjutan. 
Dalam mengembangkan pariwisata kelautan yang berkelanjutan, pemanfaatan sumberdaya alam menjadi salah satu prinsip utama yang dapat menunjang keberlanjutan pariwisata. Penelitian mengenai potensi sumberdaya alam telah banyak dilakukan diantaranya adalah penelitian Samudra dkk. (2010) tentang potensi wisata bahari pulau-pulau kecil di Kawasan Kapoposang, Kabupaten Pangkep yang dilakukan dengan metode survei dan Forum Group Discussion (FGD) dengan hasil penelitian bahwa Kawasan Kapoposan memiliki potensi yang layak untuk dikembangkan sebagai daerah wisata bahari berazaskan konservasi seperti keberadaan perikanan tangkap yang ramah lingkungan, wisata selam (Diving dan Snorkeling) dengan keanekaragaman dari terumbu karang dan ikan karang, keberadaan sarana prasarana penunjang, serta memiliki masyarakat dengan kearifan lokal dan tingkat pemahaman kesadaran atas lingkungan yang tinggi.

Hasil penelitian Herdiana (2019) yang menggunakan metode kualitatif dengan pendekatan penelitian kepustakaan menyebutkan bahwa pengelolaan desa wisata berbasis masyarakat akan berhasil jika masyarakat terlibat dalam keseluruhan proses dimana masyarakat ditempatkan dalam 2 (dua) peran sekaligus. Pertama, yaitu masyarakat sebagai subjek yang memiliki hak untuk menentukan arah pengembangan desa wisata. Kedua, masyarakat sebagai objek dengan memprioritaskan kesejahteraan masyarakat dalam pengembangan desa wisata.

Penelitian lainnya terkait dengan potensi sumberdaya alam adalah penelitian yang dilakukan oleh Astuti dan Noor (2016) tentang daya tarik Morotai sebagai destinasi wisata sejarah dan bahari yang dilakukan dengan metode observasi dan Forum Group Discussion (FGD). Hasil penelitian tersebut menunjukkan adanya daya tarik wisata sejarah Perang Dunia II dan wisata bahari mulai dari wisata selam [diving dan snorkeling], renang [swimming], memancing [fishing], serta kunjungan desa bahari sekitar Pulau Morotai. 
Adapun bentuk pengembangan dari pariwisata berkelanjutan yang membutuhkan partisipasi aktif masyarakat setempat dalam perencanaan, pengelolaan, hingga evaluasi dari kegiatan pariwisata yang disebut dengan pariwisata berbasis masyarakat [Community-based Tourism]. Dalam Amerta (2017), Pariwisata berbasis masyarakat [Community-based Tourism] merupakan bentuk pariwisata yang konsisten dan berusha untuk menyeimbangkan antara nilai-nilai sumberdaya alam, sosial dan masyarakat, sehingga dapat memberi manfaat bagi masyarakat maupun wisatawan dalam bentuk interaksi yang positif maupun pengalaman bersama yang berharga. Dalam pengembangannya, pariwisata berbasis masyarakat menjadikan masyarakat sebagai pemeran untama karena masyarakat setempat yang mengetahui potensi maupun kearifan lokal yang ada di daerah tersebut. Maka, masyarakat perlu memiliki peran baik dalam perencanaan maupun pelaksanaan kegiatan pariwisata yang berbasis masyarakat ini.

Menurut Hausler (2005) dalam Wiwin (2018), Community-based Tourism merupakan bentuk pariwisata yang memberikan kesempatan kepada masyarakat lokal untuk mengontrol dan terlibat dalam manajemen dan pengembangan pariwisata. Menurut Sunaryo dalam Rizkianto dan Topowijono (2018), Pariwisata berbasis masyarakat atau Community-based Tourism merupakan pelibatan masyarakat dengan kepastian manfaat yang diperoleh oleh masyarakat melalui upaya perencanaan dan pendampingan yang membela masyarakat lokal serta kelompok lain yang memiliki antusias atau minat kepada kepariwisataan, dengan pengelolaan pariwisata yang memberikan peluang lebih besar untuk mewujudkan kesejahteraan masyarakat setempat.

Garrod (2001) dalam A'inun, dkk. (2015) menyebutkan beberapa definisi Community-based Tourism yaitu: (1) bentuk pariwisata yang memberikan kesempatan kepada masyarakat lokal untuk mengontrol dan terlibat dalam manajemen dan pembangunan pariwisata, (2) masyarakat tidak terlibat langsung dalam usaha-usaha 
Alexander M. A. Khan, Imam Musthofa, Indarwati Aminuddin,

Fitri Handayani, Ratna N. Kuswara, Ajeng Wulandari

pariwisata juga mendapat keuntungan, (3) menuntut pemberdayaan secara politis dan demokra-tisasi dan distribusi keuntungan kepada komunitas yang kurang beruntung di pedesaan.

Prinsip dasar Community-based Tourism yang dirancang oleh UNEP dan WTO (2005) dalam Wiwin (2018) adalah sebagai berikut: (1) mengakui,mendukung dan mengembangkan kepemilikan komunitas dalam industri pariwisata ; mengikutsertakan anggota komunitas dalam memulai setiap aspek; (3) mengembangkan kebanggaan komunitas; (4) mengembangkan kualitas hidup komunitas; (5) menjamin keberlanjutan lingkungan; (6) mempertahankan keunikan karakter dan budaya di area lokal ; (7) membantu berkembangnya pembelajaran tentang pertukaran budaya pada komunitas; (8) menghargai perbedaan budaya dan martabat manusia; (9) mendistribusikan keuntungan secara adil kepada anggota komunitas ; dan (10) berperan dalam menentukan prosentase pendapatan (pendistribusian pendapatan) dalam proyek-proyek yang ada di komunitas.

Prinsip-prinsip dasar tersebut terbagi dalam beberapa kategori, diantaranya (1) prinsip sosial yang berkaitan dengan kualitas internal komunitas, (2) prinsip ekonomi yang berkaitan dengan kepemilikan usaha pariwisata dan pendistribusian keuntungan kepada anggota komunitas, (3) prinsip budaya yang berkaitan dengan upaya mempertahankan dan toleransi budaya melalui kegiatan pariwisata, (4) prinsip lingkungan yang berkaitan dengan terjaganya kualitas lingkungan dan kegiatan pariwisata, dan (5) prinsip politik yang berkaitan dengan kekuasaan untuk ikut menentukan prosentase pendapatan.

Berdasarkan prinsip dasar dan beberapa definisi, dapat disimpulkan bahwa Community-based Tourism merupakan bentuk pariwisata yang memberikan peluang bagi masyarakat untuk meningkatkan kesejahteraan dengan melakukan partisipasi aktif dalam berbagai kegiatan pengembangan pariwisata berkelanjutan dimulai dari 
perencanaan, pelaksanaan dan pengelolaan, hingga evaluasi kegiatan kepariwisataan.

Penelitian Palimbunga (2018) tentang keterlibatan masyarakat dalam pengembangan desa pariwisata menunjukkan bahwa bentuk keterlibatan masyarakat dalam pengembangan pariwisata di lokasi penelitian meliputi tahap perencanaan, pelaksanaan dan pengawasan. Namun, dari keseluruhan tahap masyarakat cenderung sebagai objek pelaksana maupun pengawas dari kegiatan yang dibuat oleh pemerintah dan cenderung bersifat satu arah.

Pengembangan suatu kawasan dapat menyebabkan perubahan dengan mengganti hal-hal lama dengan hal-hal baru (modernisasi), namun perubahan ini tidak hanya mengarah pada hal positif tetapi terdapat hal negatif. Sehingga dalam pengembangan suatu kawasan desa membutuhkan perencanaan masa depan untuk mencapai suatu tujuan. Menurut Mill (2000) dalam Sunarjaya dkk. (2018), ketiadaan perencanaan pada suatu tempat wisata dapat mengakibatkan dampak negatif berupa; (1) kerusakan atau perubahan permanen lingkungan fisik; (2) kerusakan atau perubahan permanen kawasan-kawasan historis/ budaya dan sumber-sumber alam; (3) terlalu banyak orang dan kemacetan; (4) adanya pencemaran; dan (5) masalahmasalah lalu lintas.

Maka dari itu, untuk mencapai pariwisata yang berkelanjutan selain dibutuhkan partisipasi aktif dari masyarakat, juga dibutuhkan perencanaan yang baik sebelum dilakukan pengembangan dan kerjasama baik antara masyarakat, pemerintah, dan pemangku kepentingan wisata untuk meningkatkan kualitas sumberdaya manusia maupun infrastruktur. 
Alexander M. A. Khan, Imam Musthofa, Indarwati Aminuddin,

Fitri Handayani, Ratna N. Kuswara, Ajeng Wulandari

\section{METODE PENELITIAN}

Penelitian dilaksanakan pada bulan Oktober 2019 di wilayah Labuanbajo, Nusa Tenggara Timur. Tahapan penelitian dibagi menjadi beberapa kegiatan diantaranya pengumpulan data, analisis SWOT dan penarikan kesimpulan. Dalam pengumpulan data, dilakukan pemilihan responden secara acak untuk mengisi kuisioner menggunakan metode snow-ball dimana seorang responden merekomendasikan responden berikutnya (Khan et al., 2018). Analisis strategi pengembangan dilakukan dengan menggunakat matriks strengths, weakness, opportunities dan threaths (SWOT). Jumlah setiap keriteria dalam kedua faktor dihitung dengan menggunakan rumus berikut (Nasution dkk., 2015:2):

$$
\mathrm{S}=\mathrm{N} \times \mathrm{B}
$$

Dimana:

$\mathrm{S}=$ Skor/Nilai suatu kriteria

$\mathrm{N}=$ Jumlah nilai unsur pada kriteria

$\mathrm{B}=$ Bobot nilai

Kemudian, skor setiap keriteria dijumlahkan untuk mendapatkan nilai keseluruhan dari setiap faktornya. Nilai tersebut digunakan untuk menentukan strategi pengembangan dengan matriks SWOT secara kualitatif dan kuantitatif. Skor pada total faktor internal dimasukkan sebagai nilai X, dan skor total faktor eksternal dimasukkan sebagai nilai Y (Gambar 1).

60 JUMPA Volume 7, Nomor 1, Juli 2020 


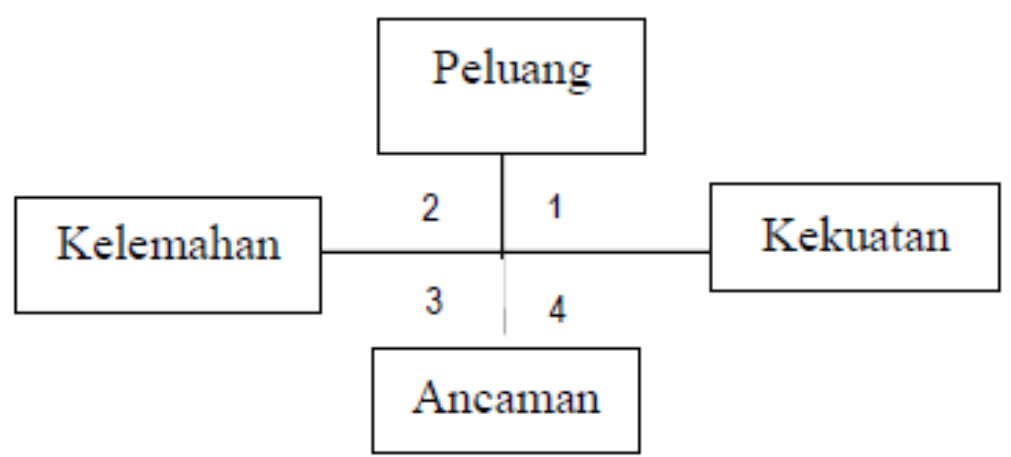

Gambar 1. Matrik SWOT

Sumber: Nasution dkk. (2015)

Sedangkan penentuan strategi pengembangan dengan matriks SWOT secara kualitatif dilakukan dengan membuat rencana pengembangan pariwisata dengan memanfaatkan kekuatan, mengambil peluang, mengurangi kelemahan dan menghindari ancaman yang dapat terjadi dalam pelaksanaan pariwisata.

\section{HASIL DAN PEMBAHASAN}

Hasil penelitian didapatkan 7 orang responden dengan usia yang beragam dan didominasi oleh laki-laki (Tabel 1).

Tabel 1. Data usia dan jenis kelamin responden

\begin{tabular}{ll}
\hline Usia & Jumlah \\
\hline$\leq 25$ tahun & 1 \\
$26-35$ tahun & 1 \\
$36-45$ tahun & 5 \\
\hline Jenis Kelamin & Jumlah \\
\hline Laki-laki & 6 \\
Perempuan & 1 \\
\hline
\end{tabular}


Alexander M. A. Khan, Imam Musthofa, Indarwati Aminuddin,

Fitri Handayani, Ratna N. Kuswara, Ajeng Wulandari

\section{Pengembangan Pariwisata Bahari}

Labuan Bajo memiliki beragam potensi sumberdaya alam untuk pariwisata, namun belum seluruhnya dikelola dan dikembangkan sehingga kegiatan pariwisata belum berjalan dengan optimal. Adapun hasil kuisioner menunjukkan seluruh responden menyebutkan bahwa di daerah mereka terdapat sumberdaya alam yang dapat dijadikan sebagai daya tarik bagi wisatawan.

Cooper (1993) dalam Sukmadewi, dkk. (2019) menyebutkan bahwa pengembangan destinasi pariwisata terdiri dari empat unsur yaitu, Attraction, Amenities, Access, Ancillary. Dalam penelitian Sukmadewi, dkk. (2019), teori ini digunakan untuk mengidentifikasi dan mengobservasi kawasan desa wisata dalam mengembangkan pariwisata khususnya untuk mengetahui potensi yang dimiliki sehingga pengembangan maupun pengelolaannya lebih terarah.

Menurut Yoeti (1996) dalam Astuti \& Noor (2016), atraksi wisata adalah segala sesuatu yang terdapat di daerah tujuan wisata yang merupakan daya tarik agar pengunjung tertarik untuk berkunjung ke suatu tempat daerah tujuan wisata. Atraksi wisata meliputi benda yang ada di alam (natural amenities), hasil ciptaan manusia (man-made supply), dan tata cara hidup masyarakat (The way of life). Adapun atraksi wisata sumberdaya alam di Labuan Bajo adalah pemandangan indah Gunung Ara dan Gunung Ina, Pemandangan indah daratan dan bawah laut Pulau Namong, Pulau Kelaki, dan Pulau Kima seperti manta dan terumbu karang, keberadaan hewan endemic Komodo, Kuda dan kerbau liar, serta pemandangan indah pada Savana, Gua Rangko, Hutan Mangrove, dan Gosong. Selain keberadaan dari sumberdaya, faktor lain dalam pengembangan wisata adalah kualitas dari sumberdaya tersebut, apakah sumberdaya tersebut sudah memiliki kualitas baik atau belum untuk dijadikan sebagai daya tarik bagi wisatawan.

62 JUMPA Volume 7, Nomor 1, Juli 2020 


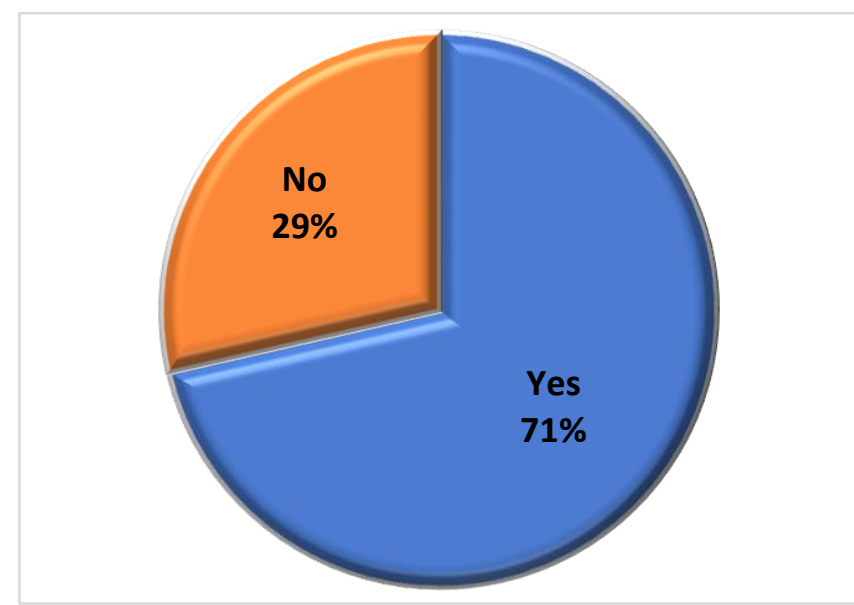

Gambar 2. Grafik kualitas sumberdaya alam Sumber: Olahan Data Peneliti (2019)

Hasil penelitian (Gambar 2), menunjukan bahwa 71\% responden mengatakan bahwa sumberdaya tersebut sudah memiliki kualitas yang baik, dan 29\% lainnya mennyebutkan sumberdaya belum memiliki kualitas yang baik karena kurangnya fasilitas umum seperti toilet, sumber air bersih, lahan untuk masyarakat berdagang, serta akses yang sulit (jalan berlumpur, tangga yang belum memadai, serta jembatan yang rusak). Kurangnya fasilitas yang ada dapat dijadikan sebagai acuan dalam optimalisasi sarana prasarana yang dapat menunjang kegiatan wisata.

Kualitas dari sumberdaya alam yang baik termasuk kedalam potensi sumberdaya kelautan, dimana menurut Samudra dkk. (2010), potensi sumberdaya kelautan yang melimpah dapat menjadi asset yang strategis dan komparatif dan dapat menjadi asset kompetitif dalam mengisi pembangunan daerah. Keberadaan dari flora dan fauna yang beragam menjadi salah satu penentu bahwa wilayah tersebut memiliki potensi sumberdaya alam yang melimpah. Kualitas sumberdaya alam dapat dijaga dan dilestarikan dengan cara melakukan kegiatan konsesrvasi yang dilakukan oleh masyarakat lokal maupun bersama dengan wisatawan. 
Alexander M. A. Khan, Imam Musthofa, Indarwati Aminuddin,

Fitri Handayani, Ratna N. Kuswara, Ajeng Wulandari

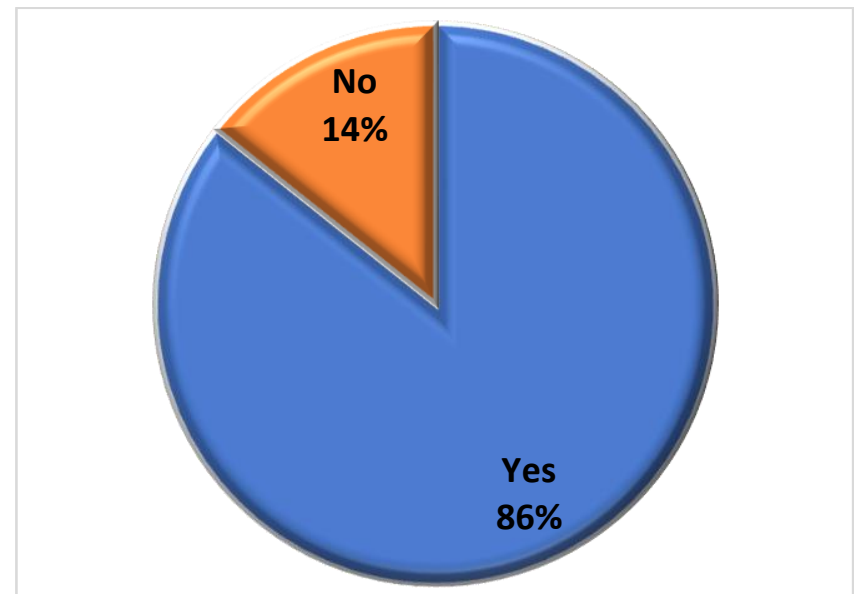

Gambar 3. Grafik Keamanan lokasi sumberdaya alam Sumber: Olahan Data Peneliti (2019)

Keamanan bagi wisatawan pun menjadi salah satu faktor yang perlu diperhatikan dalam pengembangan sumberdaya alam untuk dijadikan sebagai daya tarik bagi wisatawan. Sebanyak $86 \%$ responden menyebutkan bahwa lokasi tersebut aman untuk dikunjungi, 14\% lainnya menyebutkan lokasi tersebut tidak aman dikunjungi karena keberadaan dari hewan liar yang sulit dikendalikan (Gambar 3). Menurut Djou (2013), pelayan public dalam aspek keamanan yang perlu disiapkan dalam pelaksanaan wisata bahari adalah (1) Sumberdaya penjaga pantai yang andal, (2) SAR yang siap sedia, (3) peralatan keselamatan dasar, dan (4) peraturan-peraturan keselamatan yang berstandar. Menurut Listiowati, dkk (2020), dampak perkembangan pariwisata akan berpengaruh pada persepsi masyarakat terhadap perkembangan pariwisata di daerahnya dan persepsi masyarakat terhadap dampak perkembangan akan berpengaruh pada kualitas keamanan dan kenyamanan wisatawan pada saat mengunjungi suatu Daya Tarik Wisata (DTW).

64 JUMPA Volume 7, Nomor 1, Juli 2020 


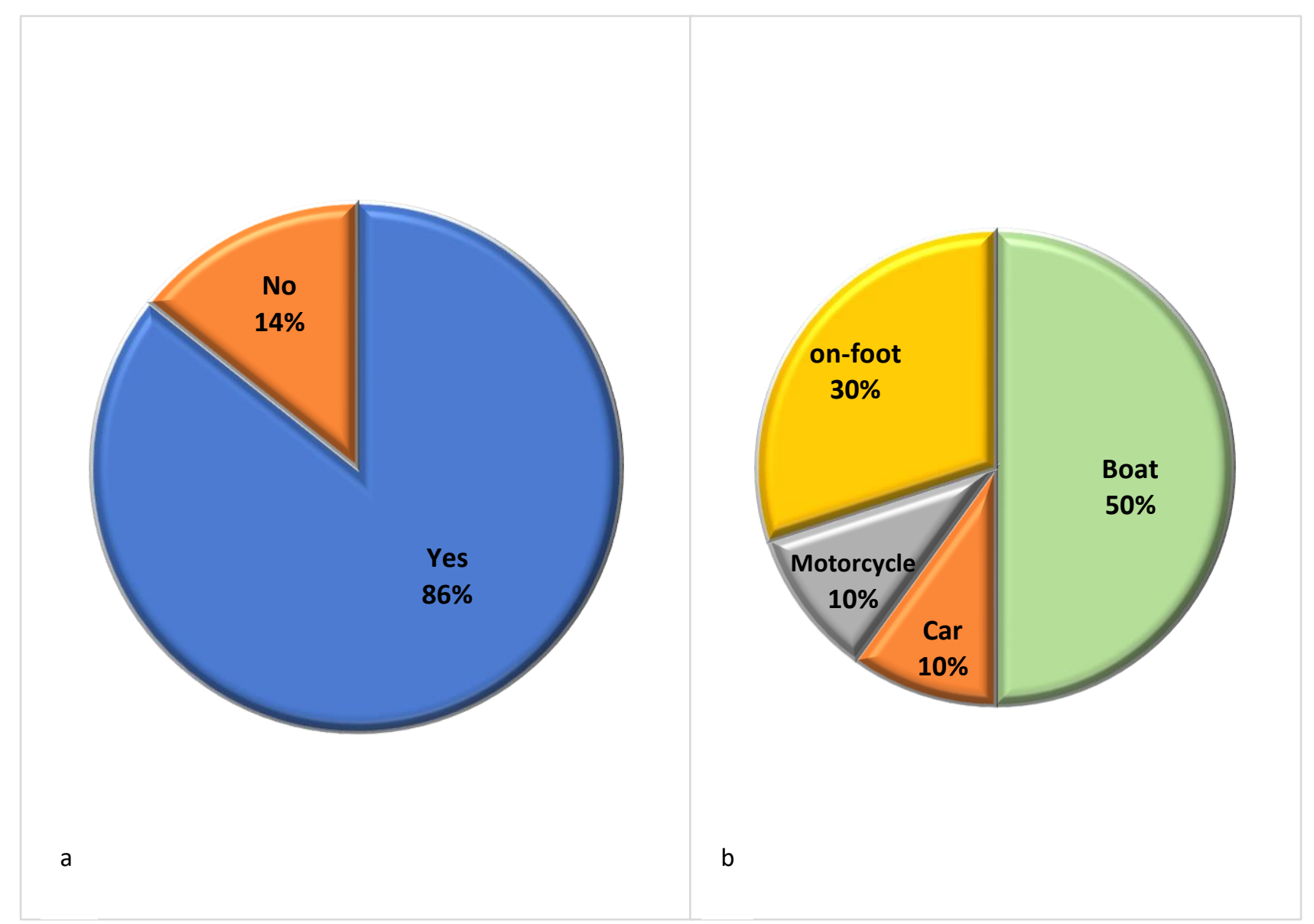

Gambar 4. (a). Grafik kemudahan Akses menuju lokasi, (b). Grafik jenis kendaraan yang dapat digunakan Sumber: Olahan Data Peneliti (2019)

Faktor lain yang perlu diperhatikan adalah kemudahan akses dan jenis kendaraan yang dapat digunakan untuk mencapai lokasi wisata tersebut. Sebanyak $86 \%$ responden (Gambar 4a), mennyebutkan bahwa akses menuju lokasi sumberdaya alam dapat ditempuh dengan mudah dan jenis kendaraan yang dapat digunakan untuk mencapai lokasi adalah menggunakan perahu dengan persentase sebanyak 50\% (gambar 4b).

Aksesibilitas termasuk kedalam komponen pariwisata menurut Cooper dkk. (2005) dalam Astuti dan Noor (2016) yang mempermudah wisatawan untuk mencapai lokasi wisata, Dalam penelitian Astuti, aksesibilitas yang tersedia lebih banyak dan 
Alexander M. A. Khan, Imam Musthofa, Indarwati Aminuddin,

Fitri Handayani, Ratna N. Kuswara, Ajeng Wulandari

beragam seperti bandara, penyewaan kendaraan, terminal bis, pelabuhan, kendaraan laut, motor dan bentor. Begitupun akses jalan utama dan jalan pendukung yang sudah baik, hanya perlu pengembangan jalan lain menuju destinasi.

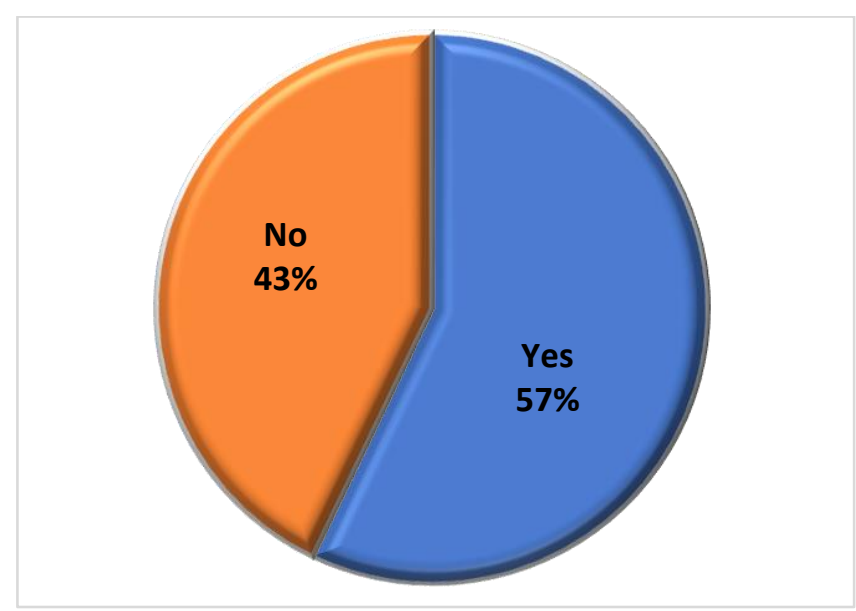

Gambar 5. Grafik keberadaan aturan adat Sumber: Olahan Data Peneliti (2019)

Keberadaan dari aturan adat tentu menjadi salah satu faktor yang dapat mempengaruhi kegian pariwisata. Menurut 57\% responden (Gambar 5), di wilayah mereka terdapat aturan adat yang mengatur kunjungan ke lokasi seperti cara berpakaian wisatawan harus sopan dan tertutup, serta wanita yang sedang menstruasi tidak diperbolehkan untuk melihat Komodo dari jarak dekat.

Aturan adat merupakan aturan yang telah dipatuhi oleh masyarakat local dimana aturan maupun kearifan lokal ini dapat menjadi salah satu potensi asset wisata sebagai pariwisata budaya (Shaleh, 2016). 


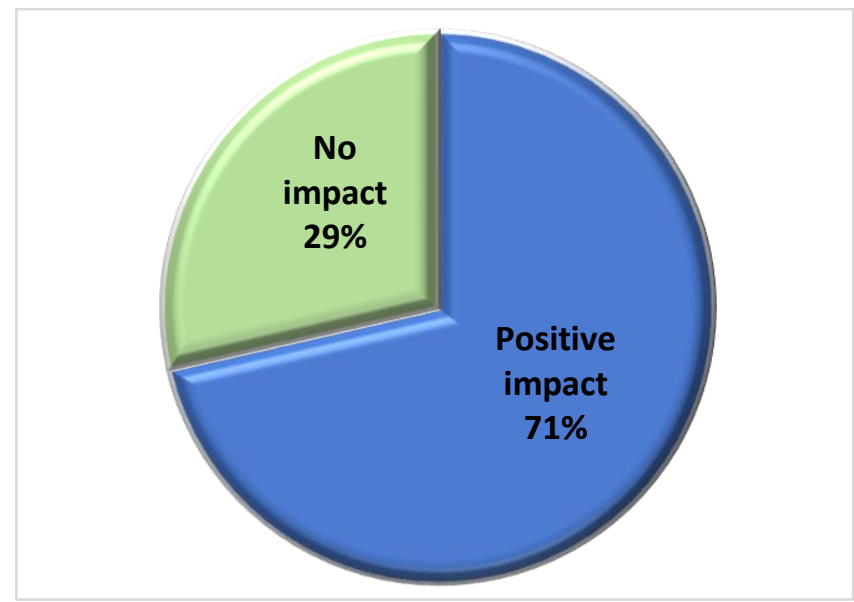

Gambar 6. Grafik Dampak Akibat Pengembangan Sumberdaya Sumber: Olahan Data Peneliti (2019)

Pengembangan berbagai sumberdaya alam sebagai daerah tujuan wisata tentu akan memberikan dampak bagi masyarakat maupun lingkungan. Pada Gambar 6, $71 \%$ responden menyebutkan bahwa pengembangan daerah wisata ini memberikan dampak positif berupa meningkatnya perekonomian masyarakat dan membuka lapangan pekerjaan baru. Sedangkan 29\% responden lainnya menyebutkan tidak ada dampak yang dirasakan dari pengembangan wisata tersebut karena pengembangan belum dilakukan dan tidak berpengaruh terhadap terjadinya kerusakan lingkungan.

Selain faktor-faktor diatas, dalam pengembangan sumberdaya alam menjadi daerah wisata terdapat kebutuhan terhadap aturan untuk mengatur pengelolaan daerah wisata, baik aturan dari pemerintah, aturan adat, maupun aturan lainnya. Hasil penelitian menunjukkan bahwa 50\% responden membutuhkan aturan pemerintah, dan 50\% lainnya membutuhkan aturan adat untuk mengatur pengelolaan Kawasan wisata alam (Gambar 7). Bentuk aturan yang dibutuhkan adalah berupa aturan jadwal kunjungan wisatawan, pengadaan biaya tiket masuk, serta aturan berpakaian bagi wisatawan. 
Alexander M. A. Khan, Imam Musthofa, Indarwati Aminuddin,

Fitri Handayani, Ratna N. Kuswara, Ajeng Wulandari

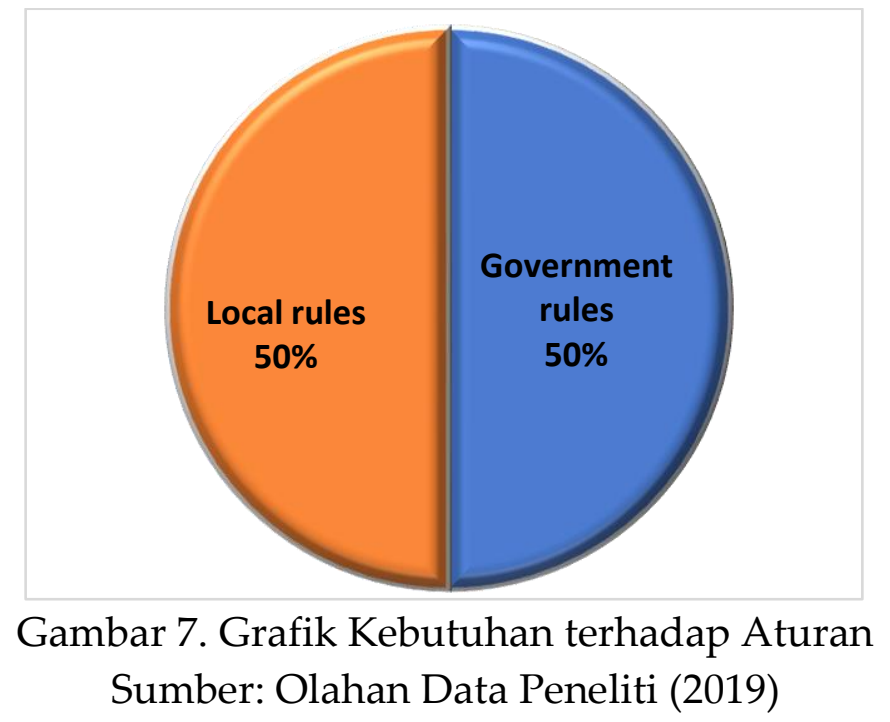

\section{Persepsi Masyarakat}

\section{Pendekatan Kuantitatif terhadap SWOT Matriks}

Masyarakat sebagai unsur utama dalam pengembangan pariwisata berbasis masyarakat yang berkelanjutan perlu memberikan penilaian tentang lokasi sumberdaya tersebut. Penilaian tersebut terdiri atas aspek kekuatan, kelemahan, peluang, serta ancaman dalam pengembangan pawiwisata yang menentukan strategi pengembangan secara kuantitatif dan kualitatif. Keempat aspek tersebut termasuk kedalam 2 faktor, yaitu faktor internal dan eksternal. 
Tabel 2. Evaluasi Kuantitatif tentang Persepsi Masyarakat untuk Faktor Internal

\begin{tabular}{lllll}
\hline No & Pertanyaan (Kekuatan) & Skor & Bobot & Total \\
\hline 1 & Kekayaan alam sebagai daya tarik wisata & 59 & 35 & 2.065 \\
2 & Kualitas sumberdaya alam & 57 & 35 & 1.995 \\
3 & Lokasi sumberdaya mudah dijangkau & 50 & 31 & 1.550 \\
4 & Keamanan dalam mengunjungi lokasi & 57 & 34 & 1.938 \\
5 & Pilihan moda transportasi menuju lokasi & 54 & 33 & 1.782 \\
6 & Keramahan penduduk di lokasi & 61 & 33 & 2.013 \\
7 & Kemudahan mendapatkan makanan & 44 & 33 & 1.452 \\
8 & Biaya transportasi, akomodasi, dan konsumsi yang terjangkau & 54 & 34 & 1.836 \\
9 & Rendahnya tingkat polusi di lokasi & 37 & 35 & 1.295 \\
10 & Adanya hukum adat yang ditaati oleh masyarakat tradisional & 47 & 35 & 1.645 \\
\hline \multicolumn{2}{c}{ Total Kekuatan } & & & 17.886 \\
\hline No & Pertanyaan (Kelemahan) Skor & Bobot & Total \\
\hline 1 & Kesadaran dalam menjaga kelestarian sumberdaya & 44 & -35 & -1.540 \\
2 & Kegiatan yang merusak lingkungan & 55 & -35 & -1.925 \\
3 & Ketersediaan sarana dan prasarana pariwisata & 41 & -35 & -1.435 \\
4 & Penerimaan masyarakat terhadap pendatang maupun & 61 & -35 & -2.135 \\
& wisatawan & & & \\
5 & Tingkat kesejahteraan masyarakat pada umumnya & 45 & -34 & -1.530 \\
6 & Tingkat Pendidikan masyarakat pada umumnya & 33 & -34 & -1.112 \\
7 & Pengetahuan masyarakat dalam menjaga kebersihan & 36 & -35 & -1.260 \\
\hline & Total Kelemahan & & & -10.937 \\
Kekuatan+kelemahan=6.949 & & & \\
\hline
\end{tabular}

Tabel 3. Evaluasi Kuantitatif tentang persepsi masyarakat

\begin{tabular}{lllll}
\hline No & Pertanyaan (Peluang) & Skor & Bobot & Total \\
\hline 1 & $\begin{array}{l}\text { Peluang sumberdaya alam yang ada di desa dijadikan daerah } \\
\text { pariwisata }\end{array}$ & 60 & 35 & 2.100 \\
2 & $\begin{array}{l}\text { Peluang menjadikan sumberdaya alam yang ada di desa } \\
\text { sebagai lokasi penelitian }\end{array}$ & 56 & 34 & 1.904 \\
3 & $\begin{array}{l}\text { Peluang melindungi sumberdaya alam yang ada melalui } \\
\text { kegiatan pariwisata }\end{array}$ & 57 & 33 & 1.881 \\
$4 \quad \begin{array}{l}\text { Peluang kerja bagi masyarakat melalui kegiatan pariwisata } \\
5\end{array}$ & 58 & 34 & 1.972 \\
$\quad \begin{array}{l}\text { Peluang meningkatkan perekonomian masyarakat melalui } \\
\text { kegiatan pariwisata berkelanjutan } \\
6\end{array}$ & 57 & 35 & 1.995 \\
$\quad \begin{array}{l}\text { Peluang masyarkat terlibat aktif dalam pengelolaan } \\
\text { sumberdaya alam melalui program pariwisata berkelanjutan }\end{array}$ & 46 & 35 & 1.610 \\
$\quad \begin{array}{l}\text { Peluang masyarakat bekerjasama dengan berbagai pihak } \\
\text { dalam mengembangkan pariwisata berkelanjutan }\end{array}$ & 58 & 35 & 2.030 \\
\hline & $\quad$ Total Peluang & & & \\
\hline
\end{tabular}


Alexander M. A. Khan, Imam Musthofa, Indarwati Aminuddin,

Fitri Handayani, Ratna N. Kuswara, Ajeng Wulandari

\begin{tabular}{lllll}
\hline No & Pertanyaan (Ancaman) & Skor & Bobot & Total \\
\hline 1 & $\begin{array}{l}\text { Kerusakan sumberdaya alam yang menjadi objek wisata } \\
\text { akibat peristiwa alam }\end{array}$ & 39 & -33 & -1.287 \\
2 & $\begin{array}{l}\text { Kerusakan sumberdaya alam yang menjadi objek wisata } \\
\text { akibat kegiatan manusia }\end{array}$ & 37 & -35 & -1.295 \\
3 & Kondisi cuaca yang tidak menentu & 48 & -33 & -1.584 \\
4 & Rendahnya kunjungan wisatawan & 52 & -35 & -1.820 \\
5 & Jaminan kemanan dan keselamatan bagi pengunjung & 49 & -35 & -1.715 \\
6 & Penutupan lokasi secara sepihak oleh masyarakat secara adat & 45 & -29 & -1.305 \\
\hline & Total Ancaman & & & -9.006 \\
Peluang+Ancaman=4.486 & & & \\
\hline
\end{tabular}

Nilai evaluasi yang didapatkan oleh faktor internal adalah 6.949 dan nilai evaluasi yang didapatkan oleh faktor eksternal adalah 4.486 (Gambar 8).

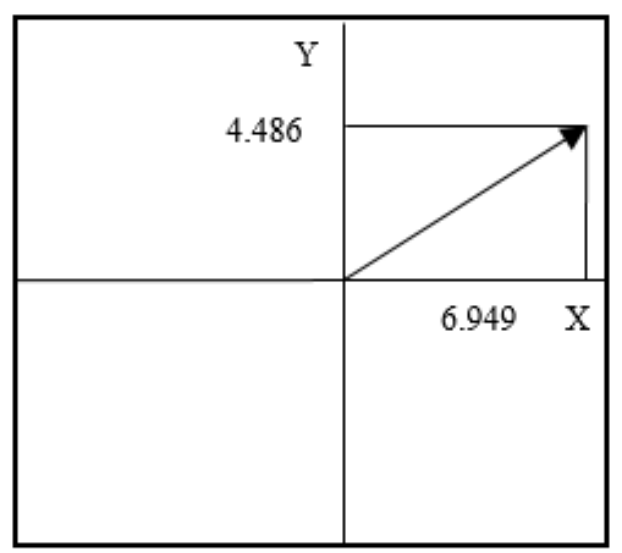

Gambar 8. Posisi Labuanbajo pada kuadran Analisis SWOT Sumber: Olahan Data Peneliti (2019)

Nilai faktor internal dan faktor eksternal memiliki niali yang positif. Nilai positif keduanya menunjukkan bahwa kekuatan yang dimiliki untuk mengembangkan sumber daya alam sebagai daya tarik wisata lebih besar dan dapat mengurangi kelemahan dan ancaman di masa depan. Berdasarkan Situmorang dan Dilham (2007), nilai pada kuadran 1 menunjukkan bahwa posisi tersebut merupakan posisi yang menguntungkan, perusahaan/kegiatan memiliki peluang dan kekuatan sehingga dapat memanfaatkan peluang yang ada secara maksimal.

70 JUMPA Volume 7, Nomor 1, Juli 2020 


\section{Pendekatan Kualitatif terhadap Matrix SWOT}

Pendekatan kualitatif SWOT dilakukan dengan membuat strategi berdasarkan setiap elemen dalam SWOT yaitu kekuatan, kelemahan, peluang, dan ancaman. Pendekatan kualitatif dalam penelitian ini dibuat berdasarkan hasil persepsi dan saran masyarakat dalam setiap elemen SWOT.

a. Strategi S-O

1. Peningkatan fasilitas publik untuk mendukung pelaksanaan kegiatan pariwisata.

2. Menyarankan dan meminta siswa dari universitas terdekat untuk melakukan penelitian di wilayah tersebut untuk melestarikan lingkungan alam dan untuk menyediakan pendidikan bagi pengunjung dan masyarakat dalam menjalankan program pariwisata berkelanjutan.

3. Menciptakan kegiatan yang dipelopori dan dikelola oleh masyarakat itu sendiri sehingga lapangan kerja dapat diciptakan, meningkatkan ekonomi masyarakat, dan meningkatkan interaksi antara masyarakat dan wisatawan.

4. Menerapkan pembayaran biaya masuk untuk meningkatkan pendapatan masyarakat dan sebagai sumber dana yang dapat digunakan dalam perlindungan manajemen sumber daya alam.

b. Strategi S-T

1. Menawarkan kenyamanan kepada pengunjung seperti penyediaan panduan dan pembangunan homestay sehingga pengunjung merasa aman dan nyaman saat mengunjungi situs.

2. Berikan tanda dan pemberitahuan kepada pengunjung untuk melindungi dan tidak merusak sumber daya alam yang ada.

3. Menawarkan kualitas dan keindahan lokasi wisata dengan cara promosi untuk menarik pengunjung. 
Alexander M. A. Khan, Imam Musthofa, Indarwati Aminuddin,

Fitri Handayani, Ratna N. Kuswara, Ajeng Wulandari

c. Streategi $\mathrm{W}-\mathrm{O}$

1. Meningkatkan kesadaran lingkungan dengan memberikan pengetahuan tentang pentingnya lingkungan kepada masyarakat dan wisatawan.

2. Meningkatkan tingkat pendidikan masyarakat.

3. Melakukan kegiatan menuju konservasi dengan melibatkan wisatawan dalam implementasinya.

4. Memberikan pelatihan kepada masyarakat tentang manajemen lingkungan yang baik.

d. Strategi W-T

1. Meningkatkan kegiatan promosi untuk meningkatkan jumlah kunjungan wisatawan.

2. Memberikan panduan waktu yang tepat untuk menegakkan sehingga pengunjung melakukan kunjungan selama kondisi alam yang baik.

3. Berikan pelatihan untuk pemandu sehingga wisatawan merasa aman selama kunjungan.

\section{KESIMPULAN}

Kesimpulan dari penelitian ini adalah:

1. Terdapat sumberdaya alam di Labuan Bajo yang dapat dijadikan sebagai daya tarik wisata namun belum dikelola dan dikembangkan dengan baik. Beberapa sumberdaya alam tersebut adalah pemandangan indah Gunung Ara dan Gunung Ina, Pemandangan indah daratan dan bawah laut Pulau Namong, Pulau Kelaki, dan Pulau Kima seperti manta dan terumbu karang, keberadaan hewan endemic Komodo, Kuda dan kerbau liar, serta pemandangan indah pada Savana, Gua Rangka, Hutan Mangrove, dan Gosong.

2. Berdasarkan pendekatan secara kuantitatif, maka strategi pengembangan yang cocok untuk dilakukan di Labuan Bajo adalah dengan Strategi S-O yang

72 JUMPA Volume 7, Nomor 1, Juli 2020 
dilakukan dengan memaksimalkan kekuatan yang dimiliki untuk mencapai peluang yang ada.

3. Berdasarkan pendekatan secara kualitatif, maka strategi yang cocok untuk dilakukan di Labuan Bajo adalah terkait dengan peningkatan fasilitas publik, kemitraan dengan universitas, peningkatan jumlah lapangan pekerjaan dan pengingkatan ekonomi daerah dan kelompok.

\section{DAFTAR PUSTAKA}

Adikampana, I. M. (2017). Pariwisata Berbasis Masyarakat. Denpasar: Cakra Press.

A'inun, F., Krisnani, H., \& Darwis, R. S. (2015). Pengembangan Desa Wisata Melalui Konsep Community Based Tourism. Prosiding Penelitian \& Pengabdian Kepada Masyarakat (pp. 341-346). Jatinangor: FISIP, Universitas Padjadjaran.

Allo, M. D., Kabanga, T., Situru, R. S., \& Dewi, R. (2018). Pariwisata Berbasis Masyarakat (Community Based Tourism) di kabupaten Tana Toraja. Kepariwisataan Berbasis Riset dan Teknologi, (pp. 148-154).

Alvi, N. N., Nurhasanah, I. S., \& Persada, C. (2018). Evaluasi Keberlanjutan Wisata Bahari Pulau Pahawang Kabupaten Pesawaran. PLANO MADANI, 59-68.

Amerta, I. M. (2017). Community Based Tourism Development. International Journal of Social Sciences and Humanities, 97-107.

Andayani, N. H., \& Yunianthini, N. (2014). Pengembangan Selancar (Surfing) Melalui Pemberdayaan Masyarakat (Community Based Tourism) di Kawasan Wisata Pantai Kuta, Kabupaten Badung. Jurnal Ilmu Sosial dan Humaniora, 351-359.

Arieta, S. 2010. Community Based Tourism pada Masyarakat Pesisir; Dampaknya Terhadap Lingkungan dan Pemberdayaan Ekonomi. Jurnal Dinamika Maritim, 71-79.

Astuti, M. T., \& Noor, A. A. 2016. Daya Tarik Morotai Sebagai Destinasi Wisata Sejarah dan Bahari. Jurnal Kepariwisataan Indonesia, 25-46.

Butarbutar, R. R., \& Soemarno. 2013. Pengaruh Aktivitas Wisatawan Terhadap Keanekaragaman Tumbuhan di Sulawesi. Journal of Indonesian Tourism and Development Studies, 87-96. 
Dewi, M. H., Fandeli, C., \& Baiquni, M. 2013. Pengembangan Desa Wisata Berbasis Partisipasi Masyarakat Lokal di Desa Wisata Jatiluwih Tabanan, Bali. KAWISTARA, 117-226.

Djou, J. A. (2013). Pengembangan 24 Destinasi Wisata Bahari Kabupaten Ende. KAWISTARA, 12-23.

Fyka, S. A., Yunus, L., Limi, M. A., Hamzah, A., \& Darwan. 2018. Analisis Dampak Pengembangan Wisata Pulau Bokori Terhadap Kondisi Sosial Ekonomi Maysarakat Bajo. HABITAT, 106-112.

Gunawan, M., \& Ortis, O. 2012. Rencana Strategis Pariwisata Berkelanjutan dan Green Jobs untuk Indonesia. Jakarta: International Labour Organization.

Hadiwijaya Lesmana Salim, \& Purbani, D. 2015. Pengembangan Pariwisata Bahari Berbasis Masyarakat di Pulau Kaledupa, Kabupaten Wakatobi, Provinsi Sulawesi Tenggara. Jurnal Manusia dan Lingkungan, 380-387.

Herdiana, D. 2019. Peran Masyarakat dalam Pengembangan Desa WIsata Berbasis Masyarakat. Jurnal Master Pariwisata (JUMPA), 63-86.

Hidayat, M. 2011. Strategi Perencanaan dan Pengembangan Objek Wisata (Studi Kasus Pantai Pangandaran Kabupaten Ciamis Jawa Barat). Tourism and Hospitality Essentials Journal , 33-44.

Listiowati, A. S., Wiranatha, A. S., \& Suryawardani, I. O. 2020. Strategi Pengembangan DTW Pantai Diamond di Dusun Pelilit, Desa Pejukutan, Nusa Penida, Klungkung, Bali. Jurnal Master Pariwisata (JUMPA), 516-540.

Mary, \& Kristanto, L. 2013. Hotel Resor dan Fasilitas Wisata Kuliner di Labuan Bajo. Jurnal eDimensi Arsitektur, 14-21.

Mudana, I. W. 2017. Pola Pemberdayaan Masyarakat pada Daerah Tujuan Wisata Bahari di Kabupaten Karangasem. Seminar Nasional Riset Inovatif (pp. 903-911). Universitas Mercu Buana.

Nasuiton, M. R., Purwoko, A., \& Hartini, K. S. 2015. Analisis Potensi dan Strategi Pembangunan Wisata Alam Air Terjun Silimalima di Kabupaten Tapanuli Selatan. 1-7.

Novalita, T., Sunaryati, R., \& Sajarwan , A. 2019. Strategi Pengembangan Wisata di Dukuh Betung Kabupaten Katingan. EnviroScienteae, 303-316.

Palimbunga, I. P. 2018. Keterlibatan Masyarakat dalam Pengembangan Pariwisata di Desa Wisata Tabalansu, Papua. Jurnal Master Pariwisata (JUMPA), 193-210. 
Putri, K. A., Dewanti, A. N., \& Muntaha, M. 2017. Penentuan Potensi Wisata Prioritas melalui Pendekatan Community Based Tourism di Desa Wisata Teritip Kota Balikpapan. Journal of Regional and Rural Development Planning, 298-306.

Rizkianto, N., \& Topowijono. 2018. Penerapan Konsep Community Based Tourism dalam Pengelolaan Daya Tarik Wisata Berkelanjutan (Studi pada Desa Wisata Bangun, Kecamatan Munjungan, Kabupaten Trenggalek). Jurnal Administrasi Bisnis, 20-26.

Samudra, K., Baskoro, M. S., Wisudo, S. H., \& Iskandar, B. H. 2010. Potensi Wisata Bahari Pulau-pulau Kecil di Kawasan Kaposang Kabupaten Pangkep. Marine Fisheries, 87-96.

Shaleh, T. M. 2016. Peran Lembaga Adat Dalam Pengelolaan Wisata Bahari (Studi Kasus di Pantai Pandawa Desa Adat Kutuh Badung-Bali). Prosiding Seminar Nasional Tahunan ke-V Hasil Penelitian Perikanan dan Kelautan, (pp. 354-365).

Silvianti, K., Yulianda, F., \& Siregar, V. P. 2017. Perencanaan Pengembangan Wisata Pantai Berbasis Potensi Sumberdaya Alam dan Daya Dukung Kawasan di Desa Sawarna, Banten. Jurnal Manusia E Lingkungan, 66-72.

Siti, A. 2010. Community Based Tourism Pada Masyarakat Pesisir; Dampaknya terhadap Lingkungan dan Pemberdayaan Ekonomi. Jurnal Dinamika Maritim, 71-79.

Situmorang, S. H., \& Dilham, A. 2007. Studi Kelayakan Bisnis (Buku II). Medan: USU Press.

Sukmadewi, N. R., Putra, I. D., \& Suardana, I. 2019. Potensi dan Pengembangan Desa Wisata Suranadi di Kecamatan Narmada Kabupaten Lombok Barat. Jurnal Master Pariwisata (JUMPA), 424-442.

Sunarjaya, I. G., Antara, M., \& Prasiasa, D. O. 2018. Kendala Pengembangan Desa Wisata Munggu, Kecamatan Mengwi, Badung. Jurnal Master Pariwisata (JUMPA), 215-227.

Wibowo, T. A., Kaskoyo, H., \& Damai, A. A. (2019). Pengembangan Wisata Pantai Mutun Terhadap Dampak Fisik, Sosial, dan Ekonomi Masyarakat Desa Sukajaya Lempasing, Kabupaten Pesawaran, Lampung. Jurnal Pengembangan Kota, 83-90.

Wiwin, I. W. (2018). Community Based Tourism dalam Pengembangan Pariwisata Bali. Pariwisata Budaya, 69-75. 
Yulianda, F. (2007). Ekowisata Bahari Sebagai Alternatif Pemanfaatan Sumberdaya Pesisir Berbasis Konservasi. Seminar Sains Departemen MSP (pp. 1-19). Bogor: FPIK IPB.

Yulius, Rahmania, R., Kadarwati, U. R., Ramdhan, M., Khairunnisa, T., Saepuloh , D., Tussaidah, A. (2018). Kriteria Penetapan Zona Ekowisata Bahari. Bogor: IPB Press.

\section{PROFIL PENULIS}

Alexander M. A. Khan, Ph.D, adalah seorang dosen di Fakultas Perikanan dan Ilmu Kelautan, Universitas Padjadjaran, Bandung. Penulis menamatkan gelar sarjana (S1) Perikanan dari Fakultas Perikanan dan Ilmu Kelautan, Universitas Riau, Pekanbaru pada tahun 2001, kemudian melanjutkan pendidikan pasca sarjana (S2) di Institut Pertanian Bogor dalam bidang Teknologi Kelautan dan mendapatkan gelas magister sains pada tahun 2005, kemudian melanjutkan pendidikan doktoral (S3) serta mendapatkan gelar doktor of philosophy (Ph.D) pada bidang fishing governance dari Newcastle University, United Kingdom pada tahun 2018.

Dr. Imam Musthofa, Director of Marine and Fisheries Program, World Wildlife Foundation-Indonesia. Alumnus (S3) Universitas Indonesia dalam bidang konservasi kelautan, dan mendapatkan gelar doktor dalam bidang biologi konservasi kelautan di Universitas Indonesia.

Indarwati Aminuddin, M.Sc Manager of Responsible Marine Tourism and Plastic Free, World Wildlife Foundation-Indonesia. Mendapatkan gelar master di Wagenigen University, the Netherland dalam bidang leisure, tourism, and environment.

Fitri Handayani, M.T Independent Consultant, World Wildlife FoundationIndonesia. Alumnus (S1) Universitas Hassanudin dalam bidang biologi, dan mendapatkan gelar master dalam bidang bioteknologi di Institut Teknologi Bandung.

Ratna N. Kuswara, M.Sc Assessor Board in Responsible Marine Tourism and Plastic Pollution Free Ocean Program "Signing Blue", World Wildlife Foundation-Indonesia. Alumnus (S1) Institut Pertanian Bogor dalam bidang Ilmu dan Teknologi Kelautan, dan mendapatkan gelar master di People's Friendship University of Rusia dalam bidang Ecology and Management of Natural Resources.

Ajeng Wulandari, S.Kel Alumnus (S1) Universitas Padjadjaran prodi Ilmu Kelautan. 